\title{
Short Communication: Characterization of Madin-Darby Bovine Kidney Cell Line for Peroxisome Proliferator-Activated Receptors: Temporal Response and Sensitivity to Fatty Acids
}

\author{
M. Bionaz, ${ }^{\star 1,2}$ C. R. Baumrucker, ${ }^{\star}$ E. Shirk, $\dagger^{3}$ J. P. Vanden Heuvel, $\dagger$ E. Block, $\ddagger$ and G. A. Varga* \\ *Department of Animal Sciences, and \\ †Department of Veterinary and Biochemical Sciences, Penn State University, University Park, PA 16801 \\ ‡Arm and Hammer Animal Nutrition Group, Church \& Dwight Co. Inc., Princeton, NJ 08543
}

\begin{abstract}
The peroxisome proliferator-activated receptors (PPAR) are critical for lipid metabolism, and many fatty acids are PPAR agonists. Madin-Darby bovine kidney (MDBK) cells were tested as an in vitro bovine model for PPAR activation, and preliminary evaluation of the effect of fatty acids on bovine PPAR was performed. Cells were treated with Wy-14643 (WY, specific PPAR $\alpha$ agonist) and rosiglitazone (ROSI, specific PPAR $\gamma$ agonist). The gene expression of specific PPAR $\alpha$-responsive genes such as carnitine palmitoyl transferase-1 $(C P T 1 A)$ and acetyl coenzyme A oxidase (ACOX1) and of PPAR $\gamma$-responsive gene lipoprotein lipase $(L P L)$ were analyzed using real-time reverse transcription PCR. It was found that CPT1A exhibited a significant increase in cells treated with WY, whereas the ACOX1 gene expression was not altered. The $L P L$ gene expression showed an increase in response to ROSI. Interestingly, $L P L$ was almost undetectable in MDBK cells not treated with ROSI. The potency of different fatty acids in activating PPAR $\alpha$ as assessed by CPT1A mRNA abundance in MDBK cells was also tested. The mRNA of CPT1A (2.5- to 1.4-fold) was significantly increased by fatty acids in the order of palmitate $>$ linolenate $>$ linoleate $>$ conjugated linoleate, and oleate. The results demonstrated MDBK cells to be responsive to PPAR agonists and thus a promising model to evaluate the role of PPAR in bovine cells. In addition, fatty acids were proven to have a different potency in modulating expression of CPT1A through PPAR $\alpha$.
\end{abstract}

Key words: Madin-Darby bovine kidney cell, peroxisome proliferator-activated receptor, fatty acid, gene expression

\footnotetext{
Received October 17, 2007.

Accepted March 12, 2008.

${ }^{1}$ Current address: Department of Animal Sciences, University of Illinois, Urbana, IL 61801.

${ }^{2}$ Corresponding author: bionaz@uiuc.edu

${ }^{3}$ Current address: Department of Molecular and Comparative $\mathrm{Pa}$ thobiology, Johns Hopkins School of Medicine, Baltimore, MD 21205.
}

In nonruminant species, peroxisome proliferator-activated receptors (PPAR) have been widely studied for their key role in many biological functions, particularly for their pivotal role in lipid metabolism (Desvergne et al., 2006). The sensitivity of PPAR to fatty acids (FA) suggests them to be important players in nutrition (Fekete and Brown, 2007). The PPAR family presents 3 subtypes called PPAR $\alpha, \operatorname{PPAR} \gamma$, and PPAR $\delta$ and $\beta$. The PPAR $\alpha$ and PPAR $\gamma$ are the most studied for their central role in lipid and glucose metabolism. Unsaturated FA, such as oleic (C18:1), linoleic (C18:2), and linolenic (C18:3), are potent activators of PPAR in nonruminant species (Desvergne and Wahli, 1999; Wahle et al., 2003). Reports describing dose-dependent responses of PPAR to FA administration have been published for humans and rodents; however, no data are available in dairy cows. Furthermore, PPAR are known to have a diverse sensitivity to different FA (Vanden Heuvel, 1999).

The effect of PPAR agonists in vivo have been studied in the goat (Cappon et al., 2002), but not in bovine, in which in vivo studies are extremely costly and timeconsuming. Therefore, preliminary studies to identify potency and doses of FA in activating PPAR are deemed necessary. Use of an in vitro system has the capacity of determining which FA are the most effective as PPAR agonist(s) and which concentrations more potently affect those nuclear receptors with a downstream effect on target genes and metabolism. Ruminants can only be treated with small amounts of FA using oral administration due to intolerance by rumen microorganisms (Jenkins, 1993). Because one of the interesting physiological effects of dietary FA is the regulation of gene expression (Pégorier et al., 2004), the amount of a specific FA should conceivably be based on the concentration and composition that induce a positive function. To our knowledge, no information exists on the type and concentration of FA that activate PPAR in ruminants. Because in vivo experiments with animals are timeconsuming, expensive, and difficult to interpret, the use of an in vitro bovine cell culture model was explored. 
The objectives of this study were as follows: (1) to evaluate the responsiveness of Madin-Darby bovine kidney cells (MDBK) to specific PPAR agonists and (2) to test the activation of PPAR in a dose-response manner by specific FA. Results could provide data to improve formulation of rumen-protected FA for the bovine to modulate the stimulatory effect of the PPAR.

Kidney cells in mammals express both the PPAR $\alpha$ gene (PPARA) and the PPAR $\gamma$ gene (PPARG; Desvergne and Wahli, 1999). The only bovine kidney cell line available is the MDBK (American Type Culture Collection \#CCL-22) that was derived from a kidney of an apparently normal adult steer by Madin and Darby (1958). The MDBK cell line used was at passage 230 and was donated by Kristen Stanton (National Animal Disease Center, Ames, IA). Cells were cultivated in a high-glucose complete Dulbecco modified Eagle's medium without pyruvate (\#SC45000-304, VWR, West Chester, PA); the same medium was used for the treatment.

To our knowledge, the responsiveness to PPAR agonists by MDBK cell line has not been explored. To investigate the responsiveness of the MDBK cells to PPAR agonists, Wy-14643 (WY) and rosiglitazone (ROSI) were utilized. The MDBK cells were treated with $50 \mu M$ of Wy-14643 and $10 \mu M$ of rosiglitazone in a 6-well plate (\#353046, BD Biosciences, San Jose, CA) with dimethyl sulfoxide (DMSO; 0.1\% vol/vol; \#MX1458-6, VWR) as control. The doses of the compounds were determined from several studies in other cell lines and systems. For example, the concentration of these compounds to activate PPAR has been examined in rat, mouse, and human cell lines (Belury et al., 1998; Bility et al., 2004) as well as monkey kidney cells (COS-1; Vanden Heuvel et al., 2006). The fact that we observed altered gene expression in the bovine cells further supports that the concentrations chosen were appropriate. Cells were washed once with $3 \mathrm{~mL}$ of phosphate buffer (\#16777247, VWR) and harvested at 0 (control), 6, 12, 18, and $24 \mathrm{~h}$ of culture with $1 \mathrm{~mL}$ of TRI Reagent (\#93289, Sigma, St. Louis, MO). Three replicates were used for each time point. The experimental design was as follows: 3 treatments $(\mathrm{WY}, \mathrm{ROSI}, \mathrm{CTR}) \times 6$ time points $\times$ 3 biological replicates (for each time point).

A second experiment was performed in which the MDBK cells were treated with palmitic acid (C16:0), oleic acid (C18:1 cis-9), linoleic acid (C18:2 cis-9,cis-12), linolenic acid (C18:3n-3), and conjugated linoleic acid (CLA; mixture of cis-9, trans-11- and trans-10, cis-12octadecadienoic acids; all from Sigma, catalog \#P0500, O1383, L1268, L2376, and O5507, respectively) at 5 concentrations $(10,25,50,100$, and $200 \mu M)$. All FA except palmitate were diluted in DMSO. Palmitate was insoluble in DMSO and was solubilized in ethanol after saponification with an equimolar amount of $\mathrm{NaOH}$. A baseline control $(98 \mu M$ or $1 \mu \mathrm{L} / \mathrm{mL}$ of DMSO for the unsaturated FA; $152 \mu M$ or $1 \mu \mathrm{L} / \mathrm{mL}$ of ethanol for palmitate) was performed in triplicate. The experimental design was as follows: 5 (FA) $\times 5$ (concentrations) $\times$ 3 (biological replicates). Cells were transferred to 6well plates and were allowed to recover overnight before the treatment that was performed for $24 \mathrm{~h}$. Cells were harvested as described above.

Total RNA was immediately extracted following the protocol suggested by Sigma and was prepared for realtime reverse transcription PCR (quantitative PCR). Briefly, $200 \mu \mathrm{L}$ of chloroform was added to $1 \mathrm{~mL}$ of TRI Reagent + cells, vortexed (15 s), and centrifuged for 15 $\mathrm{min}$ at $12,000 \times \mathrm{g}$. The supernatant was removed in a new RNase-DNase-free tube, and $0.5 \mathrm{~mL}$ of isopropanol was added and mixed by inverting the tube a few times. The mixture was set to room temperature for $10 \mathrm{~min}$ and then centrifuged for $>30 \mathrm{~min}$ at $12,000 \times \mathrm{g}$ and $4^{\circ} \mathrm{C}$. The resulting pellet was washed with $75 \%$ ethanol, centrifuged, and the dry pellet was resuspended in nuclease-free water. The RNA quantification was performed by spectrophotometer and diluted to obtain 1 $\mu \mathrm{g} / \mu \mathrm{L}$ of final concentration. The reverse transcription was performed using High Capacity cDNA Archive Kit (\#4322171, ABI, Foster City, CA) with $1 \mu \mathrm{g}$ of RNA in $50 \mu \mathrm{L}$ of total RT solution following the instructions of the manufacturer. The program was $25^{\circ} \mathrm{C}$ for $10 \mathrm{~min}$ and $37^{\circ} \mathrm{C}$ for $2 \mathrm{~h}$. The cDNA was stored at $-20^{\circ} \mathrm{C}$.

The quantitative PCR was performed using SYBR Green Master Mix ( $\# 4309155, \mathrm{ABI})$ in a $25-\mu \mathrm{L}$ reaction $(5 \mu \mathrm{L}$ of $\mathrm{cDNA}+1.5 \mu \mathrm{L}$ of $300 \mathrm{nM}$ forward primer + $1.5 \mu \mathrm{L}$ of $300 \mathrm{nM}$ reverse primer $+12.5 \mu \mathrm{L}$ of SYBR Green Master Mix $+4.5 \mu \mathrm{L}$ of DNase-RNase-free water) with a 5-point 10 -fold dilution standard curve. Standard curve was obtained by pooling part of total RNA from all samples. The final data were obtained transforming the cycle threshold $(\mathbf{C t})$ values using the standard curve.

All primers used were previously published (Table 1) except for lipoprotein lipase $(\boldsymbol{L P L})$ that was designed using the free available software Primer3. The PCR product of the primer pair was tested running a $2 \%$ agarose gel containing ethidium bromide to check the presence of a single product and primer-dimer. The $L P L$ PCR product was sequenced to verify correct gene amplification.

Relative expression of PPARA and PPARG, carnitine palmitoyl transferase-1A (CPT1A); acyl-coenzyme A oxidase 1 (ACOX1); LPL, and glyceraldehyde phosphate dehydrogenase (housekeeping gene; GAPD) was determined. The use of GAPD as an internal control was chosen primarily because it was widely used in many biological experiments. We did not observe a sig- 
Table 1. Sequences and features of primers used for quantitative PCR

\begin{tabular}{|c|c|c|c|c|c|}
\hline Gene $^{1}$ & & Primer & $\begin{array}{l}\text { Size } \\
(\mathrm{bp})\end{array}$ & $\begin{array}{l}\text { Accession } \\
\text { no. }\end{array}$ & Reference \\
\hline$G A P D$ & $\begin{array}{l}\text { Forward } \\
\text { Reverse }\end{array}$ & $\begin{array}{l}\text { GTCTTCACTACCATGGAGAAGG } \\
\text { TCATGGATGACCTTGGCCAG }\end{array}$ & 197 & U85042 & Inderwies et al., 2003 \\
\hline$A C O X 1$ & $\begin{array}{l}\text { Forward } \\
\text { Reverse }\end{array}$ & $\begin{array}{l}\text { CCATTGCCGTCCGATACAGT } \\
\text { GTTTATATTGCTGGGTTTGATAATCCA }\end{array}$ & 99 & TC262400 & Loor et al., 2005 \\
\hline CPT1A & $\begin{array}{l}\text { Forward } \\
\text { Reverse }\end{array}$ & $\begin{array}{l}\text { CAAAACCATGTTGTACAGCTTCCA } \\
\text { GCTTCCTTCATCAGAGGCTTCA }\end{array}$ & 111 & AF284831 & Loor et al., 2005 \\
\hline$P P A R A$ & $\begin{array}{l}\text { Forward } \\
\text { Reverse }\end{array}$ & $\begin{array}{l}\text { CGGTGTCCACGCATGTGA } \\
\text { TCAGCCGAATCGTTCTCCTAAA }\end{array}$ & 56 & ВT020756 & Loor et al., 2005 \\
\hline$P P A R G$ & $\begin{array}{l}\text { Forward } \\
\text { Reverse }\end{array}$ & $\begin{array}{l}\text { AATAACGCGATTCGTTTTGG } \\
\text { TCCATGTCGTGGATGAGAAA }\end{array}$ & 233 & AF229356 & MacLaren et al., 2005 \\
\hline$L P L$ & $\begin{array}{l}\text { Forward } \\
\text { Reverse }\end{array}$ & $\begin{array}{l}\text { GACAGGATGTGGCCAAGTTT } \\
\text { AAAATCCGCATCATCAGGAG }\end{array}$ & 220 & BC118091 & This manuscript \\
\hline
\end{tabular}

${ }^{1} G A P D=$ glyceraldehyde phosphate dehydrogenase; $A C O X 1=$ acetyl coenzyme A oxidase $C P T 1 A=$ carnitine palmitoyl transferase-1; PPARA and PPARG = peroxisome proliferator-activated receptors $\alpha$ and $\gamma$; and $L P L=$ lipoprotein lipase.

nificant $(P>0.05)$ effect of treatments in expression of $G A P D$. However, we understand the limitation of such approach knowing that more genes should be evaluated before choosing the more reliable one and at the least 3 internal control genes should be used, as reported previously (Bionaz and Loor, 2007). After normalization, data are reported as fold change compared with time 0 (control). Statistical analysis was performed using the REPEATED statement of the MIXED procedure of SAS (release 8.0, SAS Inst. Inc., Cary, NC). The statistical model included treatment (C16:0, C18:1, C18:2, C18:3, and CLA or WY, ROSI, DMSO), FA concentrations $(0,10,25,50,100$, and $200 \mu M)$ or time points $(0,6,12,18$, and 24$)$, biological replicate (within treatment; $\mathrm{n}=3$ ), and treatment $\times$ concentration or time point. The covariance structure used was spatial power. The significance was declared at $P<0.05$ and trends discussed when $P<0.10$.

The MDBK cells expressed $>25$-fold greater mRNA abundance of PPARG when compared with PPARA (calculated by $\triangle \mathrm{Ct}$; median $\mathrm{Ct}$ was 23.2 and 28.0 , respectively). Both $C P T 1 A$ and $A C O X 1$ have been shown to be $\operatorname{PPAR} \alpha$-specific downstream genes in nonruminant animals (Varanasi et al., 1996; Desvergne et al., 2006). For this reason, the temporal expression of the 2 genes were tested in cells treated with WY, a potent and specific PPAR $\alpha$ agonist (Desvergne and Wahli, 1999). The $L P L$ gene has been demonstrated to be activated by PPAR $\gamma$ (Desvergne and Wahli, 1999), and the temporal expression of the gene was measured in cells treated with ROSI. All treatments were compared with the DMSO control.

The expression of PPARA and PPARG was not affected by PPAR agonists (data not shown). The MDBK cells exhibited a response to PPAR agonists shown by the increase in expression of $C P T 1 A$ and $L P L$ (2.5-fold and $>200$-fold compared with time 0 at 24 and $18 \mathrm{~h}$, respectively; Figure 1). Both genes demonstrated a significant activation at $24 \mathrm{~h}$ of incubation compared with time 0 and DMSO treatment. Furthermore, MDKB cells treated with $50 \mu M$ of WY for $24 \mathrm{~h}$ showed a similar magnitude of CPT1A gene expression induction when compared with $100 \mu M$ of the same drug used in mouse primary hepatocytes (Guo et al., 2006). Although the MDBK cells not treated with rosiglitazone presented a very low expression of $L P L$ (almost undetectable; $\mathrm{Ct}$ $>35$ ), they had a large response in $L P L$ mRNA expression with ROSI treatment, confirming $L P L$ to be a PPAR $\gamma$ target gene also in the bovine, as reported for other species (Desvergne and Wahli, 1999). The same concentration of rosiglitazone for $24 \mathrm{~h}$ in fetal rat primary brown adipocytes showed a $>2$-fold increase of $L P L$ (Teruel et al., 2005). The low abundance of $L P L$ in MDBK cells was unexpected, because $L P L$ activity is reported to be elevated in the kidney in nonruminant species (Ruge et al., 2004); however, the low mRNA abundance of $L P L$ in nontreated cells may be due to the very low concentration of FA in the culture medium. The DMSO treatment showed a large effect on $L P L$ induction $(\sim 50$-fold at $12 \mathrm{~h}$ incubation; $P<0.01)$. The very low mRNA abundance of $L P L$ and the high response to DMSO precluded the use of the gene to test the activation of $L P L$ by fatty FA unless another solvent is utilized. Nevertheless, the increase in $L P L$ expression by ROSI was remarkable and is shown in Figure 1 (lower panel).

The ACOX1 gene is strongly regulated by PPAR $\alpha$ agonists in nonruminant species (Tugwood et al., 1992; Duplus and Forest, 2002). In MDBK cells, expression of $A C O X 1$ was not significantly activated by the PPAR 

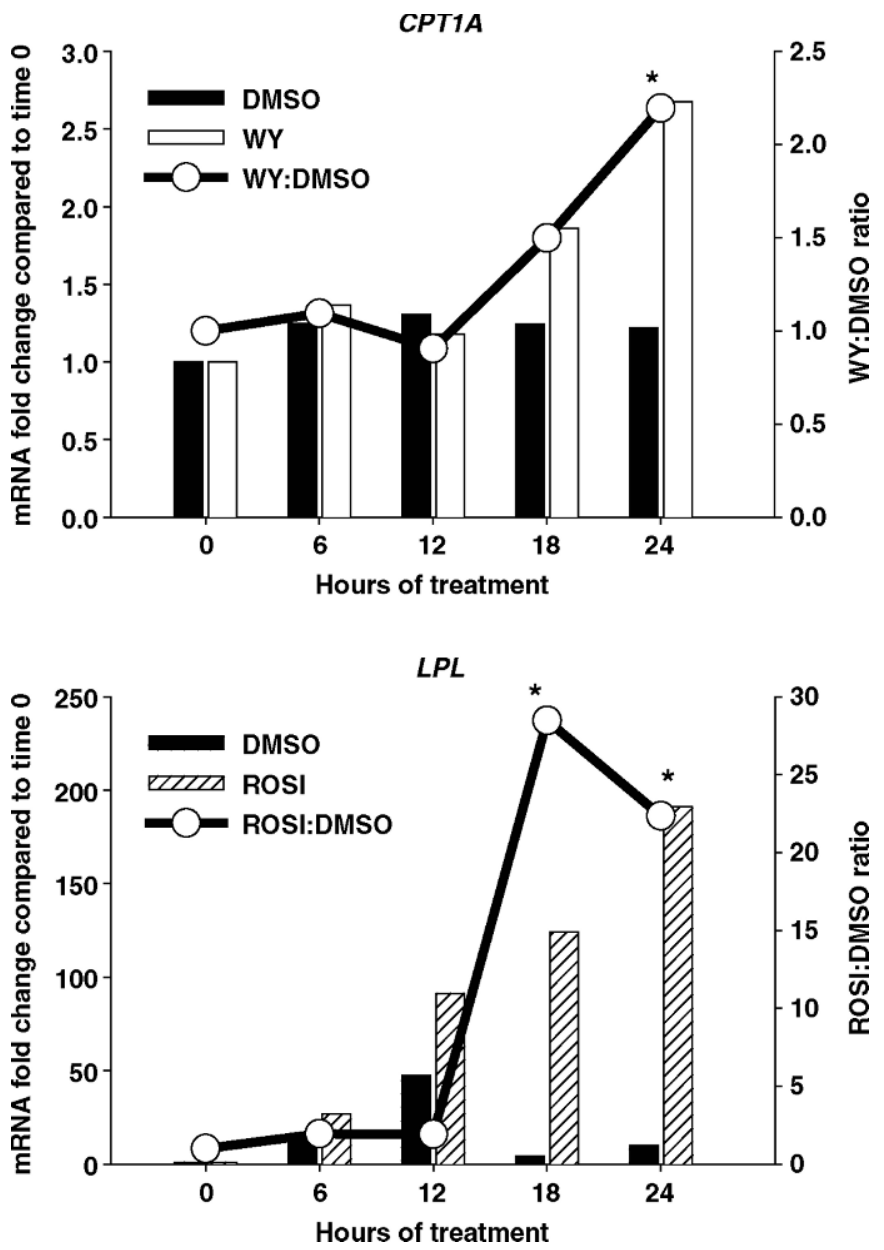

Figure 1. Expression of carnitine palmitoyl transferase-1 (CPT1A) and lipoprotein lipase $(L P L)$ in Madin-Darby bovine kidney (MDBK) cells. $C P T 1 A$ [Wy-14643 (WY) $P<0.01 ; \mathrm{SEM}=0.06$ and dimethyl sulfoxide (DMSO) $P=0.49 ; \mathrm{SEM}=0.04]$ response after $50 \mu M \mathrm{WY}$ treatment and $L P L$ [rosiglitazone (ROSI) $P<0.01$; SEM $=1.6$ and DMSO $P<0.01$; SEM $=0.08$ ] response after $30 \mu M$ ROSI treatment. Asterisk denotes significant difference $(P<0.05)$ compared with time 0 for WY:DMSO and ROSI:DMSO.

agonist WY (data not shown). The lack of activation of ACOX1 in MDBK cells could be a consequence of cell line immortalization that requires cell adaptation to the in vitro environment. However, the data are puzzling, because MDBK cells present a relative high ACOX1 mRNA abundance. To verify if bovine $A C O X 1$ is a $\operatorname{PPAR} \alpha$-responsive gene, an in vivo investigation may be needed or another bovine cell line should be tested.

Results from the previous experiments demonstrated $C P T 1 A$ to be an appropriate gene to investigate the activation of PPAR $\alpha$. Based on this observation, we measured CPT1A perturbation, in MDBK cells after treatment with 5 different $\mathrm{FA}$, in 5 increasing concentrations for $24 \mathrm{~h}$.
The 16:0, 18:1 cis-9, and 18:2 cis-9, cis-12 FA were chosen based on their high concentrations in bovine plasma (Rukkwamsuk et al., 1999), whereas 18:3n-3 was chosen because its concentration tends to increase in plasma of cows on pasture (Chilliard and Ferlay, 2004). All these FA are well established as PPAR $\alpha$ agonists in mice (Desvergne and Wahli, 1999). Bovine plasma presents a noteworthy concentration of CLA (Loor et al., 2005) that originates from ruminal biohydrogenation of polyunsaturated FA (Beam et al., 2000) and by the endogenous activity of steroyl-CoA desaturase on absorbed 18:1 trans-11 (Griinari et al., 2000). Beside the demonstrated negative effect of 18:2 trans10 , cis-12 on expression of genes involved in milk fat synthesis in mammary gland (Peterson et al., 2004), the CLA proved to be a potent $\operatorname{PPAR} \alpha$ agonist in mice (Takahashi et al., 2003).

Results of the dose-response experiments of the $5 \mathrm{FA}$ in activating PPAR $\alpha$ are shown in Figure 2. The CPT1A gene expression was increased by all the FA at different doses (overall effect $P<0.01$ ), except oleic acid $(P=$ 0.25 ). None of the FA were significantly effective at a doses $<100 \mu M$. At $100 \mu M$ concentration, only 3 FA showed a significant effect: palmitate was the most potent [ 2.5-fold vs. control (CTR)] followed by $18: 3 \mathrm{n}-3$ and CLA ( $>1.5$ - and 1.4-fold vs. DMSO control, respectively). At $200 \mu M, 18: 3 \mathrm{n}-3$ showed the strongest effect ( 2.5 -fold vs. DMSO control) followed by palmitate (2.2fold vs. CTR); C18:2 cis-9, cis-12; CLA; and C18:1 cis-9 (2.1-, 1.8-, and 1.4-fold vs. DMSO control, respectively). Palmitate at $200 \mu M$ tended to have a negative effect on cell survival (almost 1/3 of the cells were detached from the plate after $24 \mathrm{~h}$ of incubation). Thus, this effect may have confounded data for CPT1A. The CLA showed a negative effect on $C P T 1 A$ expression at $10-\mu M$ concentration $(-2.0$-fold vs. CTR; $P<0.01)$; this could be a consequence of the high concentration of DMSO in the control (98 $\mu M$ or $1 \mu \mathrm{L} / \mathrm{mL}$ ), which corresponded to the dose of DMSO + FA used to obtain the maximum FA concentration $(200 \mu M)$. In preliminary results, DMSO has been shown to increase CPT1A mRNA abundance in a dose-dependent manner (data not shown). As a consequence, the induction of CPT1A by unsaturated FA could be underestimated.

In mice, palmitate exhibited some activity in activating PPAR $\alpha$ (Desvergne and Wahli, 1999). In mice and human, oleic, linoleic, and CLA have been shown to be potent activators of PPAR (Moya-Camarena and Belury, 1999; Khan and Vanden Heuvel, 2003; Kota et al., 2005). In our study, the response to the unsaturated FA was less effective; however, all of the tested FA showed a positive trend in increasing CPT1A expression, and all of them, except for oleic acid, significantly activated PPAR $\alpha$ at a dose of $200 \mu M$. At the same 


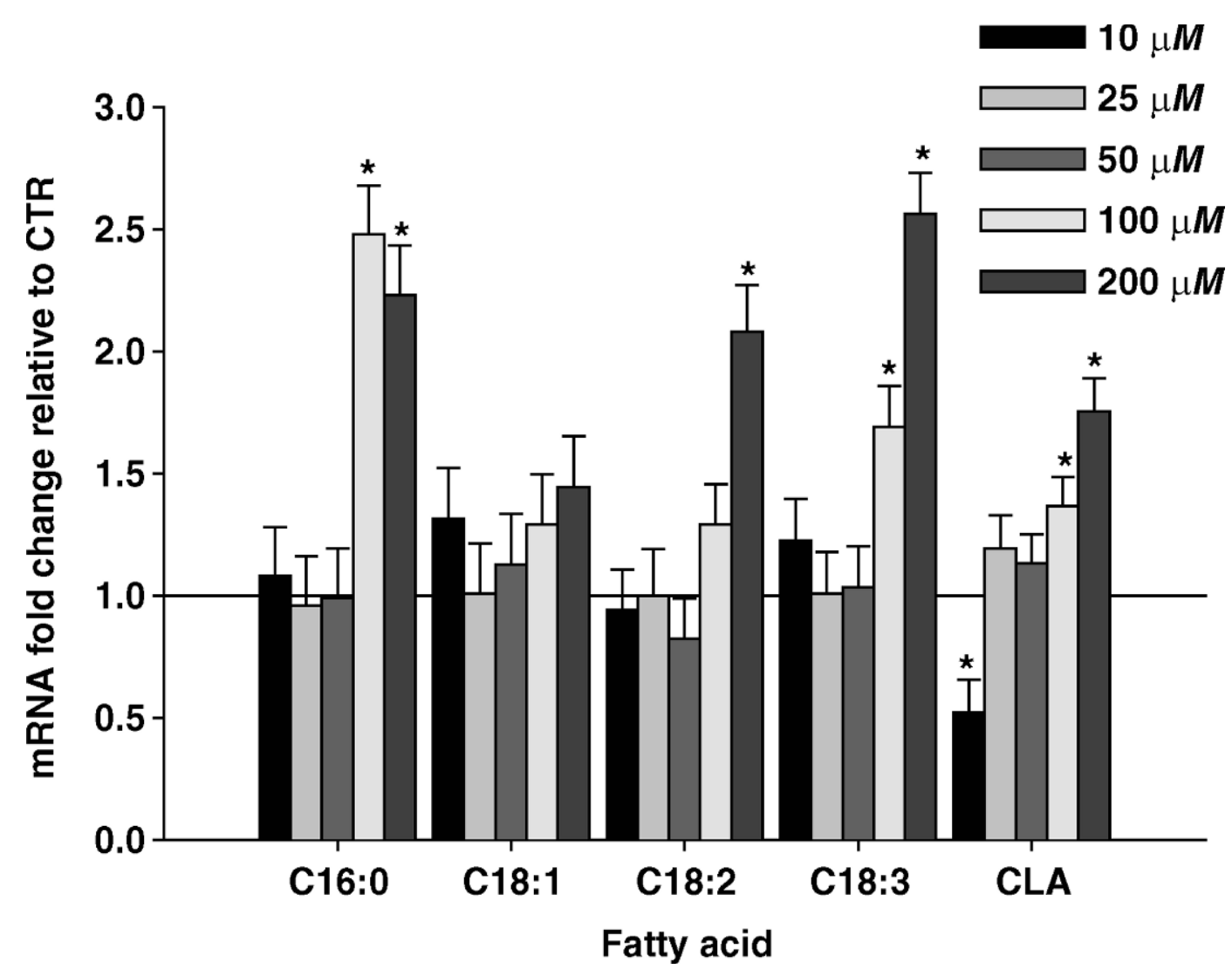

Figure 2. Expression of carnitine palmitoyl transferase-1 (CPT1A) with increasing concentrations of palmitic acid (C16:0), oleic acid (C18:1), linoleic acid (C18:2), linolenic acid (C18:3), and a mix of conjugated linoleic acid (CLA) on Madin-Darby bovine kidney cells. Data are reported as fold change compared with ethanol for palmitate and dimethyl sulfoxide for the other fatty acids (control, or CTR, indicated by the threshold at 1). A tendency for the effect of oleic acid at $200 \mu M$ on CPT1A expression was observed $(P=0.053)$; however, overall effect on CPT1A expression for this fatty acid was not significant. Asterisk denotes $P<0.05$.

dose, oleic acid exhibited a tendency to increase CPT1A mRNA abundance. This suggests that greater concentrations need to be evaluated.

Overall, the results for the time course experiment suggest that MDBK cells are a promising model to investigate the effect of FA on PPAR. Data from the time point trial using specific PPAR agonists suggest that the minimum incubation time of the cells with FA should be $18 \mathrm{~h}$. The CPT1A appears to be a good target gene to test the PPAR $\alpha$ activation in MDBK cells. Nevertheless, we are aware that to obtain reliable data, more than one gene should be used to evaluate the activation of PPAR $\alpha$ and that primary cells (i.e., bovine hepatocytes) should be a more appropriate model to infer in vivo effects. The $L P L$ showed a tremendous response to ROSI, but the low expression of the gene in MDBK cells remains an issue.

The dose-response experiment allows us to conclude that palmitate is a potent $\operatorname{PPAR} \alpha$ activator in MDBK cells, as are linolenic and linoleic acids. In our system, $100 \mu M$ was the minimum concentration that affected
$\operatorname{PPAR} \alpha$ activation for 16:0, 18:3, and CLA. The oleic and linoleic acids required higher doses $(200 \mu M)$. The maximum concentration used in the experiment was $200 \mu M$ based on previous publications, most of which were performed in mice, a species with an extremely high sensitivity to PPAR activation (Lai, 2004). Our data showed that the sensitivity of MDBK cells for specific PPAR agonists, such as Wy-14643 and ROSI, appears to be comparable to rodents. Moreover, differently than nonruminant species, the PPAR $\alpha$ in MDBK cells tended to be less responsive to unsaturated FA compared with palmitate, the only saturated FA tested. It is tempting to propose that bovine PPAR are more sensitive to saturated FA than unsaturated; maybe this is an evolutionary adaptation, because ruminants present high concentrations of saturated FA in plasma. To verify this hypothesis, the bovine MDBK cells should be treated with stearate. However, as mentioned above, the different potency in activating CPT1A expression, between palmitate and unsaturated FA, could be due 
to the different control group used. More data are required to confirm those preliminary results.

The data generated in these experiments support a role for FA as a candidate for nutrient modulation of metabolism in the bovine. Potential applications might lie in improved nutrition and methods to deal with metabolic problems of dairy cows, especially during the transition from pregnancy to lactation. In fact, PPAR have been suggested to be important for this critical period in dairy cows (Drackley, 1999), and a very recent report uncovered a positive effect of treatment of transition cows with thiazolidinedione, a specific $\mathrm{PPAR} \gamma$ activator (Smith et al., 2007).

\section{ACKNOWLEDGMENTS}

The project was supported by Church \& Dwight Co. Inc. We also acknowledge the financial support of M. Bionaz by the Congrégation du Grand-Saint-Bernard (http://www.gsbernard.ch/).

\section{REFERENCES}

Beam, T. M., T. C. Jenkins, P. J. Moate, R. A. Kohn, and D. L. Palmquist. 2000. Effects of amount and source of fat on the rates of lipolysis and biohydrogenation of fatty acids in ruminal contents. J. Dairy Sci. 83:2564-2573.

Belury, M. A., S. Y. Moya-Camarena, H. Sun, E. Snyder, J. W. Davis II, M. L. Cunningham, and J. P. Vanden Heuvel. 1998. Comparison of dose-response relationships for induction of lipid metabolizing and growth regulatory genes by peroxisome proliferators in rat liver. Toxicol. Appl. Pharmacol. 151:254-261.

Bility, M. T., J. T. Thompson, R. H. McKee, R. M. David, J. H. Butala, J. P. Vanden Heuvel, and J. M. Peters. 2004. Activation of mouse and human peroxisome proliferator-activated receptors (PPARs) by phthalate monoesters. Toxicol. Sci. 82:170-182.

Bionaz, M., and J. J. Loor. 2007. Identification of reference genes for quantitative real-time PCR in the bovine mammary gland during the lactation cycle. Physiol. Genomics 11:312-319.

Cappon, G. D., R. C. Liu, S. R. Frame, and M. E. Hurtt. 2002. Effects of the rat hepatic peroxisome proliferator, Wyeth 14,643, on the lactating goat. Drug Chem. Toxicol. 25:255-266.

Chilliard, Y., and A. Ferlay. 2004. Dietary lipids and forages interactions on cow and goat milk fatty acid composition and sensory properties. Reprod. Nutr. Dev. 44:467-492.

Desvergne, B. A., L. Michalik, and W. Wahli. 2006. Transcriptional regulation of metabolism. Physiol. Rev. 86:465-514.

Desvergne, B., and W. Wahli. 1999. Peroxisome proliferator-activated receptors: Nuclear control of metabolism. Endocr. Rev. 20:649688.

Drackley, J. K. 1999. Biology of dairy cows during the transition period: The final frontier? J. Dairy Sci. 82:2259-2273.

Duplus, E., and C. Forest. 2002. Is there a single mechanism for fatty acid regulation of gene transcription? Biochem. Pharmacol. 64:893-901.

Fekete, S. G., and D. L. Brown. 2007. Veterinary aspects and perspectives of nutrigenomics: A critical review. Acta Vet. Hung. $55: 229-239$.

Griinari, J. M., B. A. Corl, S. H. Lacy, P. Y. Chouinard, K. V. Nurmela, and D. E. Bauman. 2000. Conjugated linoleic acid is synthesized endogenously in lactating dairy cows by $\Delta^{9}$ desaturase. J. Nutr. 130:2285-2291.

Guo, L., H. Fang, J. Collins, X. H. Fan, S. Dial, A. Wong, K. Mehta, E. Blann, L. Shi, W. Tong, Y. P. Dragan. 2006. Differential gene expression in mouse primary hepatocytes exposed to the peroxisome proliferator-activated receptor alpha agonists. BMC Bioinformatics 7(Suppl 2):S18.

Jenkins, T. C. 1993. Lipid metabolism in the rumen. J. Dairy Sci. 76:3851-3863.

Khan, S. A., and J. P. Vanden Heuvel. 2003. Role of nuclear receptors in the regulation of gene expression by dietary fatty acids. J. Nutr. Biochem. 14:554-567.

Kota, B. P., T. H. Huang, and B. D. Roufogalis. 2005. An overview on biological mechanisms of PPARs. Pharmacol. Res. 51:85-94.

Lai, D. Y. 2004. Rodent carcinogenicity of peroxisome proliferators and issues on human relevance. J. Environ. Sci. Health C Environ. Carcinog. Ecotoxicol. Rev. 22:37-55.

Loor, J. J., A. Ferlay, A. Ollier, K. Ueda, M. Doreau, and Y. Chilliard. 2005. High-concentrate diets and polyunsaturated oils alter trans and conjugated isomers in bovine rumen, blood, and milk. J. Dairy Sci. 88:3986-3999.

Madin, S. H., and N. B. Darby. 1958. Established kidney cell lines of normal adult bovine and ovine origin. Proc. Soc. Exp. Biol. Med. 98:574-576.

Moya-Camarena, S. Y., and M. A. Belury. 1999. Species differences in the metabolism and regulation of gene expression by conjugated linoleic acid. Nutr. Rev. 57:336-340.

Pégorier, J. P., C. Le May, and J. Girard. 2004. Control of gene expression by fatty acids. J. Nutr. 134:2444S-2449S.

Peterson, D. G., E. A. Matitashvili, and D. E. Bauman. 2004. The inhibitory effect of trans-10, cis-12 CLA on lipid synthesis in bovine mammary epithelial cells involves reduced proteolytic activation of the transcription factor SREBP-1. J. Nutr. 134:25232527.

Ruge, T., L. Neuger, V. Sukonina, G. Wu, S. Barath, J. Gupta, B. Frankel, B. Christophersen, K. Nordstoga, T. Olivecrona, and G. Olivecrona. 2004. Lipoprotein lipase in the kidney: Activity varies widely among animal species. Am. J. Physiol. 287:F1131-F1139.

Rukkwamsuk, T., T. A. Kruip, G. A. Meijer, and T. Wensing. 1999. Hepatic fatty acid composition in periparturient dairy cows with fatty liver induced by intake of a high energy diet in the dry period. J. Dairy Sci. 82:280-287.

Smith, K. L., S. E. Stebulis, M. R. Waldron, and T. R. Overton. 2007. Prepartum 2,4-thiazolidinedione alters metabolic dynamics and dry matter intake of dairy cows. J. Dairy Sci. 90:3660-3670.

Takahashi, Y., M. Kushiro, K. Shinohara, and T. Ide. 2003. Activity and mRNA levels of enzymes involved in hepatic fatty acid synthesis and oxidation in mice fed conjugated linoleic acid. Biochim. Biophys. Acta 1631:265-273.

Teruel, T., R. Hernandez, E. Rial, A. Martin-Hidalgo, and M. Lorenzo. 2005. Rosiglitazone up-regulates lipoprotein lipase, hormone-sensitive lipase and uncoupling protein-1, and down-regulates insulin-induced fatty acid synthase gene expression in brown adipocytes of Wistar rats. Diabetologia 48:1180-1188.

Tugwood, J. D., I. Issemann, R. G. Anderson, K. R. Bundell, W. L. McPheat, and S. Green. 1992. The mouse peroxisome proliferator activated receptor recognizes a response element in the 5 ' flanking sequence of the rat acyl CoA oxidase gene. EMBO J. 11:433-439.

Vanden Heuvel, J. P. 1999. Peroxisome proliferator-activated receptors: A critical link among fatty acids, gene expression and carcinogenesis. J. Nutr. 129:575S-580S.

Vanden Heuvel, J. P., J. T. Thompson, S. R. Frame, and P. J. Gillies. 2006. Differential activation of nuclear receptors by perfluorinated fatty acid analogs and natural fatty acids: A comparison of human, mouse, and rat peroxisome proliferator-activated receptor- $\alpha,-\beta$, and $-\gamma$, liver $\times$ receptor- $\beta$, and retinoid $\times$ receptor- $\alpha$. Toxicol Sci. 92:476-489.

Varanasi, U., R. Chu, Q. Huang, R. Castellon, A. V. Yeldandi, and J. K. Reddy. 1996. Identification of a peroxisome proliferatorresponsive element upstream of the human peroxisomal fatty acyl coenzyme A oxidase gene. J. Biol. Chem. 271:2147-2155.

Wahle, K. W., D. Rotondo, and S. D. Heys. 2003. Polyunsaturated fatty acids and gene expression in mammalian systems. Proc. Nutr. Soc. 62:349-360. 